\title{
SERE, a widely dispersed bacterial repetitive DNA element
}

\author{
G. RAJASHEKARA, T. KOEUTH*, S. NEVILE, A. BACK, K. V. NAGARAJA, J. R. LUPSKI* \\ and $V$. KAPUR \\ Department of Veterinary PathoBiology, University of Minnesota, St Paul, MN 55108 and *Department of \\ Molecular and Human Genetics, Baylor College of Medicine, Houston, TX 77030, USA
}

\begin{abstract}
The presence of a Salmonella serotype Enteritidis repeat element (SERE) located within the upstream regulatory region of the $\operatorname{sef} A B C D$ operon encoding fimbrial proteins is reported. DNA dot-blot hybridisation analyses and computerised searches of genetic databases indicate that SERE is well conserved and widely distributed throughout the bacterial and archaeal kingdoms. A SERE-based polymerase chain reaction (SEREPCR) assay was developed to fingerprint 54 isolates of Enteritidis representing nine distinct phage types and 54 isolates of other Salmonella serotypes. SERE-PCR identified five distinct fingerprint profiles among the 54 Enteritidis isolates; no correlation between phage types and SERE-PCR fingerprint patterns was noticed. SERE-PCR was reproducible, rapid and easy to perform. The results of this investigation suggest that the limited heterogeneity of SERE-PCR fingerprint patterns can be utilised to develop serotype- and serogroup-specific fingerprint patterns for isolates of Enteritidis.
\end{abstract}

\section{Introduction}

Several short, non-coding, inter-cistronic repetitive DNA sequences have been identified in prokaryotes [1], including the repetitive extragenic palindrome (REP) [2-4], enterobacterial repetitive intergenic consensus (ERIC) $[5,6]$ and BOX elements of Streptococcus pneumoniae [7]. The highly conserved nature and the widespread distribution of these repeat sequences in the bacterial genome have facilitated their use in the genetic fingerprinting of bacteria - for example, repetitive sequence-based polymerase chain reaction (rep-PCR), in which a DNA sequence, similar or identical to the repeat sequence, is used as primer to generate a specific pattern or genomic DNA fingerprint $[1,8,9]$. In previous studies, rep-PCR-generated fingerprints have been found to be species- or strainspecific and have proved useful for strain typing [811]. Because of its ease of use and discriminatory power, rep-PCR has become an important tool with which to fingerprint bacteria involved in outbreaks of disease and to determine the sources and vehicles of transmission $[1,10-12]$.

In this study, the existence of a novel, highly-

Received 13 May 1997; revised version accepted 2 Oct. 1997.

Corresponding author: Dr V. Kapur. conserved repetitive DNA element located within the regulatory region of the sefABCD operon of the Enteritidis genome and its application in a PCR assay (SERE-PCR) for the genetic fingerprinting of isolates of Enteritidis and other serotypes of Salmonella from diverse O-serogroups are described.

\section{Materials and methods}

\section{Bacterial strains}

The properties of 54 isolates of $S$. Enteritidis (Table 1) and 54 isolates of other serotypes of Salmonella of diverse O-serogroups (Table 2) used in this study are shown. The sources of other bacterial species used in dot-blot hybridisation assays have been described previously [13]. Strains of Salmonella Typhi (2304), Citrobacter diversus (5403), Enterobacter sakazakii (4584) and Str. pneumoniae (424) were kindly provided by Dr E. O. Mason, Texas Childrens Hospital, Houston, TX, USA. Other strains were from the culture collections of the authors.

\section{Isolation of chromosomal DNA}

Bacteria were grown in Luria-Bertani (LB) broth, or were scraped directly from LB agar plates, and chromosomal DNA was extracted as described earlier [13]. 
Table 1. Properties of 54 isolates of Salmonella serotype Enteritidis

\begin{tabular}{|c|c|c|c|}
\hline Strain no. & Source, state (if USA) or country & Phage type & Fingerprint pattern \\
\hline CAllo & Chicken intestine, CA & 1 & B \\
\hline M46 & Chicken ovary, ME & 2 & $\mathrm{C}$ \\
\hline M47 & Environment, ME & 2 & $\mathrm{C}$ \\
\hline M48 & Environment, $\mathrm{ME}$ & 2 & $\mathrm{C}$ \\
\hline Call* & Cat intestine, $\mathrm{CA}$ & 4 & B \\
\hline $\mathrm{Cal} 2$ & Chicken liver, CA & 4 & B \\
\hline Cal3 & Chicken liver, CA & 4 & B \\
\hline $\mathrm{Cal} 4$ & Mouse liver, CA & 4 & A \\
\hline Cal5 & Chicken ovary, CA & 4 & B \\
\hline Cal6 & Creek water, CA & 4 & B \\
\hline Cal7 & Skunk liver, CA & 4 & B \\
\hline Cal8 & Chicken egg, CA & 4 & B \\
\hline Cal11 & Creek water, CA & 4 & B \\
\hline Call2 & Creek water, CA & 4 & B \\
\hline Cal13 & Creek water, CA & 4 & B \\
\hline Cal14 & Sewage, CA & RDNC & B \\
\hline Cal15 & Sewage, CA & RDNC & B \\
\hline Cal16 & Mouse liver, CA & 4 & B \\
\hline Cal17 & Sewage, CA & 4 & B \\
\hline Cal9 & Chicken liver, CA & 7 & B \\
\hline M49 & Chicken, Venezuela & $7 \mathrm{var}$ & $\mathrm{C}$ \\
\hline B7001 & Chicken ovary, GA & 8 & $\mathrm{C}$ \\
\hline M29 & Chicken organ, $\mathrm{ME}$ & 8 & C \\
\hline M470 & Visceral organ, broiler, $\mathrm{ME}$ & 8 & $\mathrm{C}$ \\
\hline CD14 & Chicken, TX & 8 & $\mathrm{C}$ \\
\hline N17 & Turkey, CO & 8 & $\mathrm{C}$ \\
\hline 35054 & Chicken, MN & 8 & $\mathrm{C}$ \\
\hline 4051 & Chicken, MN & 8 & $\mathrm{C}$ \\
\hline 3842 & Chicken, MN & 8 & $\mathrm{C}$ \\
\hline M50 & Cloaca of hen, ME & $9 b$ & $\mathrm{C}$ \\
\hline N8 & Duck, MD & $9 b$ & $\mathrm{C}$ \\
\hline M23 & Environment, ME & 13 & $\mathrm{C}$ \\
\hline M25 & Chicken, ME & $13 \mathrm{a}$ & $\mathrm{C}$ \\
\hline B6996 & Human, GA & $13 \mathrm{a}$ & $\mathrm{C}$ \\
\hline $\mathrm{CD} 2$ & Restaurant, NJ & $13 a$ & $\mathrm{C}$ \\
\hline CD11 & Chicken, NJ & $13 \mathrm{a}$ & $\mathrm{C}$ \\
\hline M28 & Cat faeces, ME & $13 \mathrm{a}$ & $\mathrm{C}$ \\
\hline M33 & Chicken gut, ME & $13 a$ & C \\
\hline M34 & Chicken visceral organ, $\mathrm{ME}$ & $13 \mathrm{a}$ & $\mathrm{C}$ \\
\hline M35 & Chicken ovary, ME & $13 \mathrm{a}$ & $\mathrm{C}$ \\
\hline M36 & Chicken visceral organ, ME & $13 \mathrm{a}$ & $\mathrm{C}$ \\
\hline M44 & Cat faeces, ME & $13 a$ & $\mathrm{C}$ \\
\hline M45 & Egg belt, ME & $13 \mathrm{a}$ & $\mathrm{C}$ \\
\hline 75-Li-De & Chicken liver, ME & $14 \mathrm{~b}$ & $\mathrm{C}$ \\
\hline $75 \mathrm{~EB} 3$ & Environment, ME & $14 b$ & $\mathrm{C}$ \\
\hline M17 & Visceral organ of hen, ME & $14 b$ & $\mathrm{C}$ \\
\hline M39 & Egg belt, ME & $14 \mathrm{~b}$ & $\mathrm{C}$ \\
\hline M42 & Egg follicle, $\mathrm{ME}$ & $14 b$ & $\mathrm{C}$ \\
\hline M43 & Environment, ME & $14 b$ & D \\
\hline N4 & Cat, MA & 28 & $\mathrm{C}$ \\
\hline N9 & Goose, MA & 28 & $\mathrm{C}$ \\
\hline SE28 & Chicken, MN & 28 & $\mathrm{C}$ \\
\hline $\mathrm{N} 2$ & Chicken, Spain & RDNC & $\mathrm{E}$ \\
\hline M40 & Chicken ovary, ME & NK & $\mathrm{C}$ \\
\hline
\end{tabular}

RDNC, reacts but does not conform to specific phage type; NK, not known.

${ }^{*}$ Isolates designated Call-Cal8 and Cal11-Cal17 are from an outbreak in a layer flock.

\section{Oligonucleotide synthesis and PCR analysis}

All synthetic oligonucleotide primers used in these studies were obtained from Integrated DNA Technologies Inc. (Ames, IA, USA) or the Nucleic Acids Core Facility (Dept of Molecular and Human Genetics, Baylor College of Medicine, TX, USA). Reagents and enzymes used for PCR were obtained from Perkin Elmer (Foster City, CA, USA). Amplification reactions were performed in $30-\mu \mathrm{l}$ volumes with primer $50 \mathrm{pmol}$, $5 \mathrm{mM} \mathrm{MgCl} 2$ and genomic DNA $100 \mathrm{ng}$ as a template in a DNA thermal cycler (Perkin Elmer, Cetus 480). Amplification reactions were performed twice to confirm assay reproducibility. Conditions for amplifica- tion included an initial denaturation at $95^{\circ} \mathrm{C}$ for $5 \mathrm{~min}$, followed by 35 cycles of denaturation $\left(94^{\circ} \mathrm{C}\right.$ for $\left.1 \mathrm{~min}\right)$, annealing $\left(50^{\circ} \mathrm{C}\right.$ for $\left.1 \mathrm{~min}\right)$, extension $\left(72^{\circ} \mathrm{C}\right.$ for $\left.2 \mathrm{~min}\right)$ and a final extension $\left(72^{\circ} \mathrm{C}\right.$ for $\left.15 \mathrm{~min}\right)$. PCR products were analysed on an agarose gel $1.5 \% \mathrm{w} / \mathrm{v}$, stained with ethidium bromide $0.5 \mathrm{mg} / \mathrm{L}$ and photographed under UV transillumination.

\section{$5^{\prime}$ End-labelling of oligonucleotide probe}

Oligonucleotide primer SERE (50 pmol) was endlabelled with $5 \mu \mathrm{l}$ of $\left[\gamma^{32} \mathrm{P}\right] \mathrm{ATP}$ (specific activity $4500 \mathrm{Ci} / \mathrm{mmole}$; ICN Pharmaceuticals Inc., Costa Mesa, CA, USA) and T4 polynucleotide kinase (New 
Table 2. Serotypes of Salmonella examined

\begin{tabular}{ll}
\hline O-serogroup & Serotype \\
\hline B & $\begin{array}{c}\text { Abortusequi, Agona, Chester, Derby, Brandenburg, Heidelberg, Indiana, Newbrunswick, Saintpaul, Schwarzengrund, } \\
\text { Typhimurium }\end{array}$ \\
C1 & Bareilly, Braenderup, Livingstone, Montevideo, Oranienburg, Tennessee \\
C2 & Blockley, Glostrup, Hadar, Newport \\
C3 & Albany, Kentucky \\
D1 & Berta, Dublin, Durban, Eastbourne, Gallinarum, Javiana, Moscow, Miami, Panama, Pullorum, Rostock \\
D2 & Fresno \\
E1 & Anatum, Westhampton \\
E2 & Binza, Cambridge, Portsmouth, Rosenthal \\
E3 & Thomasville \\
E4 & Chittagong, Senftenberg \\
G1 & Chameleon, Havana \\
G2 & Putten, Worthington \\
I & Gaminara \\
J & Berlin \\
M & Pomana \\
O & Urbana \\
Q & Alachua \\
\hline
\end{tabular}

England Biolabs, Beverly, MA, USA) $20 \mathrm{U}$ at $37^{\circ} \mathrm{C}$ for $45 \mathrm{~min}$ and the reaction was stopped by adding $0.5 \mathrm{M}$ EDTA $(2 \mu 1)$. Probe was purified from the unincorporated label by ultrafiltration through Microcon 3 filters, according to the manufacturer's instructions (Amicon Inc., Beverly, MA, USA).

\section{DNA dot-blot hybridisation}

A dot-blot membrane [13] containing chromosomal DNA from 44 bacterial and archaeal species from seven phyla [14], was prepared by blotting chromoso- mal DNA from specific bacterial and archaeal species (Fig. 2). Chromosomal DNA (100 ng) was diluted in distilled water $300 \mu \mathrm{l}$, heated at $100^{\circ} \mathrm{C}$ for $5 \mathrm{~min}$ and spotted on to a hybridisation membrane. DNA was denatured in situ with $0.4 \mathrm{~N} \mathrm{NaOH}$, rinsed with $1 \times \mathrm{SSC}(0.15 \mathrm{M} \mathrm{NaCl}, 0.015 \mathrm{M}$ trisodium citrate $)$, dried by blotting with filter paper and baked at $80^{\circ} \mathrm{C}$ for $1 \mathrm{~h}$. Hybridisation solution was prepared as described previously [13]. The membrane was prehybridised at $65^{\circ} \mathrm{C}$ for $2 \mathrm{~h}$ and hybridised at $65^{\circ} \mathrm{C}$ for $18 \mathrm{~h}$ with denatured radiolabelled probe. After hybridisation, the blot was washed twice with $2 \times \mathrm{SSC}$ at room

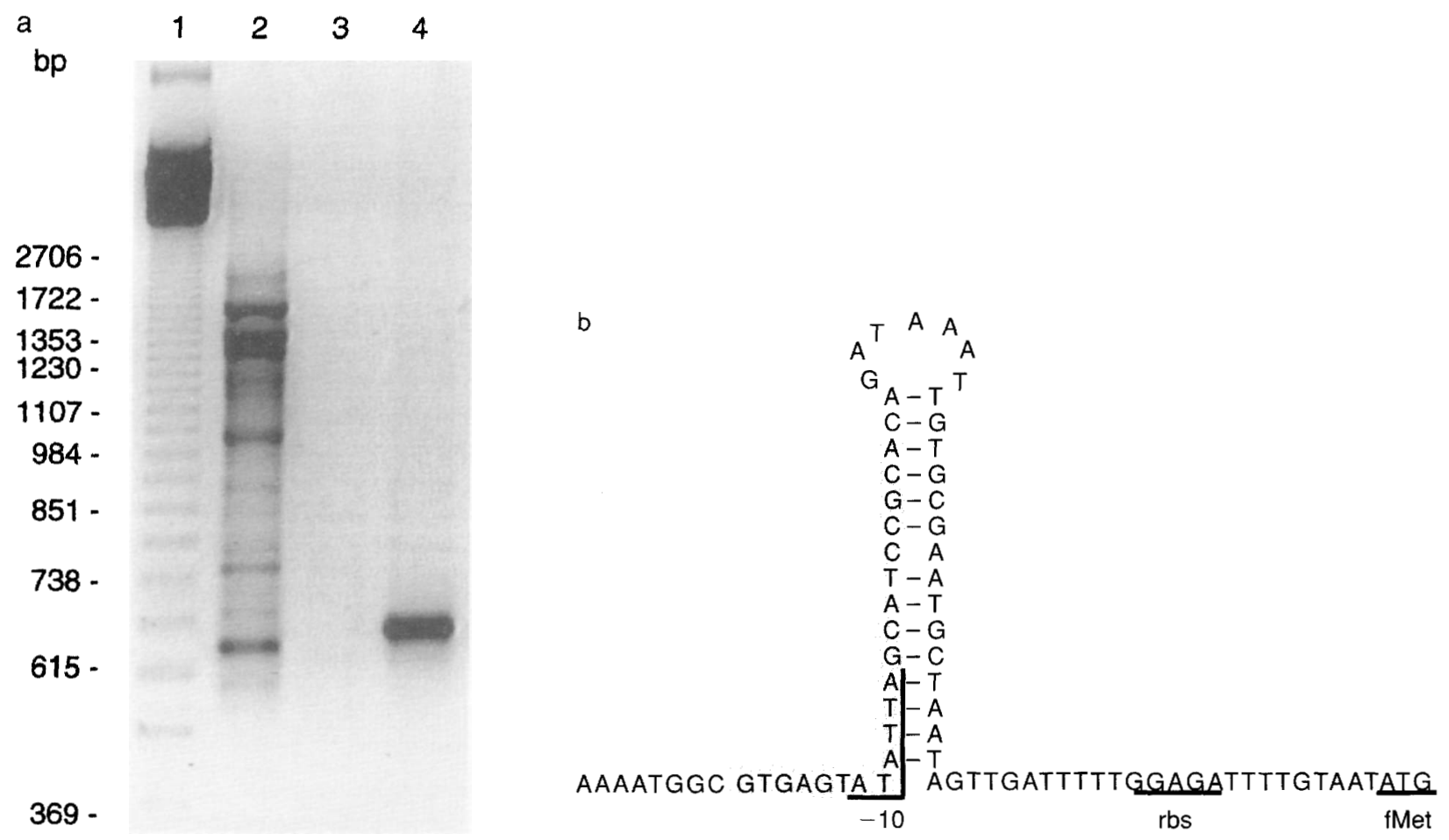

Fig. 1. a, PCR amplification of chromosomal DNA of Enteritidis with: SERE alone (lane 2); sefA reverse primer (5'TAGTTTTGATACTGCTGAACGTAG) alone (3); both SERE and sefA reverse primer (4). A 123-bp DNA ladder (lane 1) was used as mol.wt standard. b, secondary structure of the promoter region of the sefABCD operon, showing involvement of SERE sequence (nucleotide positions 9-27 in dashed box) and possible association with the promoter region. The -10 region, ATG f-Met start codon and the ribosome binding site (rbs) are underlined. 
temperature for $5 \mathrm{~min}$ and once with $2 \times \mathrm{SSC} / \mathrm{SDS}$ $0.02 \% \mathrm{w} / \mathrm{v}$ for $5 \mathrm{~min}$. The blot was then exposed to Hyperfilm (Amersham Life Science Inc., Arlington Heights, IL, USA) with two intensifying screens at $-80^{\circ} \mathrm{C}$ for $18-24 \mathrm{~h}$.

\section{Southern blot hybridisation}

Chromosomal DNA $(1 \mu \mathrm{g})$ from various bacterial and archaeal species was digested with combinations of restriction endonucleases: either $B a m \mathrm{HI} / E c o \mathrm{RI}$ or Bam HI/Eco RI/Hind III or Bam HI/Hind III. The restriction endonucleases were used at $40 \mathrm{U} /$ reaction and digestion was at $37^{\circ} \mathrm{C}$ for $12 \mathrm{~h}$. Digested DNA samples were separated on an agarose gel $1 \% \mathrm{w} / \mathrm{v}$, stained with ethidium bromide $0.5 \mathrm{mg} / \mathrm{L}$ and transferred to a Sure Blot Hybridisation membrane by capillary transfer at room temperature for $15 \mathrm{~h}$. DNA on the membrane was prehybridised and then hybridised with end-labelled oligonucleotide probe, and blots were developed as described above.

\section{Results}

\section{$A$ repetitive DNA sequence (SERE)}

Single primer-based PCR with sequence 5'-GTGAGTATATTAGCATCCGCA resulted in amplification of several distinct DNA fragments of 400-2500 bp from Enteritidis chromosomal DNA (Fig. 1a). One copy of this repeat sequence, designated $S$. Enteritidis repeat element (SERE), is located within the regulatory region (Fig. 1b) of the Enteritidis sef $A B C D$ operon [15, 16]. A subsequent computerised search of DNA sequence databases (GenBank release 91) identified several bacterial and archaeal species containing sequences showing high $(>70 \%)$ sequence similarity with SERE (Table 3).

Table 3. Alignment of repeat units from different bacterial and archaeal species

\begin{tabular}{|c|c|c|c|}
\hline Species or serotype & Gene/locus & $\begin{array}{l}\text { Accession } \\
\text { number }\end{array}$ & Nucleotide sequence \\
\hline$S$. Enteritidis & $\operatorname{sefA}$ & L03833 & G T G A G TA TA T TA G CA T C C G C A \\
\hline S. Typhimurium & phoE & X03928 & G T G A G T A T c a $T$ c G C A T C a G C A \\
\hline S. Typhi & phoE & X74595 & G T G A G T A T c a T c G C A T C a G C A \\
\hline S. Pullorum & citC & D10257 & 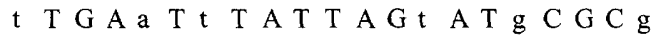 \\
\hline Escherichia coli & $a p t-a d k$ & M38777 & $\mathrm{G} T \mathrm{~T}$ t $\mathrm{G}$ a $\mathrm{AT}$ A T T A $t$ t A T C C G C A \\
\hline Haemophilus influenzae & hiu32784 & U32784 & G T G A G T g a A g $\mathrm{TAc}$ C A g C C G C A \\
\hline Klebsiella pneumoniae & dha & U30903 & 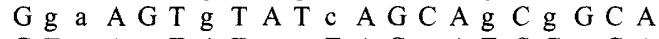 \\
\hline Neisseria gonorrhoeae & por & X53824 & G $T$ c A a $T$ A $T$ t a $T$ A G t A T C C c C A \\
\hline N. meningitidis & $23 r R N A$ & $\mathrm{X} 67300$ & G c c A G T A a A c T g G C A T C C G C A \\
\hline Pseudomonas aeruginosa & oprL & Z50191 & t $T$ G A g A T A c g A C A T C a G C A \\
\hline Proteus mirabilis & PRMFLI & L07270 & G T G A c T A T t T T A C t T C t c C A \\
\hline Serratia marcescens & SMACHITA & L38484 & G T G c G T A c A g T A c g A a C C G C A \\
\hline Vibrio cholerae & fur & M85154 & G T G A $\mathrm{c}$ A $\mathrm{A}$ A $\mathrm{c}$ c A G C A T C a $\mathrm{t}$ C A \\
\hline Xanthomonas campestris & avrbS3-2 & X78781 & G T G A c T A c c T G A G C g T C g G C A \\
\hline Campylobacter fetus & $\operatorname{sap} A 2$ & S76860 & G T G A t T g T A T T A C A T C a a C A \\
\hline C. jejuni & rpoB & X77304 & G T G A a A T t T T A a C $\mathrm{ACC}$ a C A \\
\hline Actinobacillus pleuropneumoniae & hemolysin & M65808 & c c G A G A T A T T A t C A T g C G A \\
\hline Flavobacterium meningosepticum & FVBASPENDO & L37784 & G T G A t T g T A a T A C A T C a G C g \\
\hline Mycoplasma gallisepticum & atp & $\mathrm{X} 64256$ & G T G A T T A $T$ g $c$ T A G A g g C G \\
\hline M. genitalium & $m g p A$ & M31431 & G T G A c T t T A T a A $\mathrm{t}$ C A T C t G a A \\
\hline Shigella boydii & sbul4469 & U14469 & a $T$ G c $\mathrm{G} \mathrm{T} \mathrm{t}$ T A T a A $\mathrm{At}$ A $\mathrm{T}$ g C G C A \\
\hline Arthrobacter sp. & $f c b A B C$ & M93187 & $\mathrm{t}$ T G A $\mathrm{A}$ A g A T T A $\mathrm{t}$ C A g C C C c \\
\hline Bacillus subtilis & $m c p, t l p A$ & L29189 & $\mathrm{t} T \mathrm{~T}$ A $\mathrm{t}$ T A $\mathrm{CA}$ g a A a C A T C C C A \\
\hline Clostridium acetobutylicum & $l y c$ & M68865 & G T G A T A T A a $c$ A G $\mathrm{t}$ A a $C$ a a $C A$ \\
\hline Chlamydia psittaci & $o m p A$ & X12647 & G T G A c g c c A T T A G C A T C G C g \\
\hline Deinococcus radiodurans & DNApol & L14581 & G c G A g A g t T T c a C A T C C G C A \\
\hline Halobacterium halobium & $i \operatorname{sh} 26-1$ & $\mathrm{X} 04832$ & G T G A g A T c T TA $t$ t $g$ T a C G C A \\
\hline Leptospira biflexa & $\operatorname{trp} E G$ & M22468 & G T G A G T A T g c T A G C A g g C G g A \\
\hline Lactobacillus lactis & $23 r R N A$ & X68435 & G T G A a A T c T T A t C c a C C G \\
\hline Listeria monocytogenes & $\sec A$ & L32090 & $\mathrm{G} g$ a $\mathrm{A} G \mathrm{~T}$ A a $\mathrm{g} T \mathrm{~T}$ c $\mathrm{GCA} \mathrm{C} \mathrm{C} \mathrm{C}$ a $\mathrm{CA}$ \\
\hline Methanobacterium thermoautotrophicum & MTU19364 & U19364 & $\mathrm{G} T \mathrm{~T}$ A G T A T c $\mathrm{c} T \mathrm{~T}$ G C A g C C $\mathrm{CA}$ \\
\hline Mycobacterium leprae & $U 00020$ & U00020 & G T G A T T A $T$ A g $\mathrm{g}$ A $\mathrm{g}$ A c C C G C c \\
\hline Nostoc sp. & NOSFTZOOP & L32796 & G T G A t T A T g a T A t C A c t C G C A \\
\hline Rhodobacter capsulatus & hupRl & M63670 & 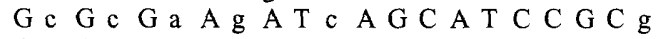 \\
\hline Rhizobium meliloti & fixF & M18272 & 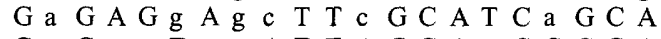 \\
\hline Rhodobacter sphaeroides & nifU & M86823 & G c G g a $T$ c g A T T A G C A c C C C A \\
\hline Streptococcus agalactiae & $\operatorname{cps} D$ & L09116 & $\mathrm{t}$ T G A t T A T A T A t CA T $\mathrm{T}$ a $t$ A \\
\hline Staphylococcus aureus & STAORPHI & L19300 & G T c A T T t T A a $T$ A G a $t$ T C $t$ G C A \\
\hline Str. equi & emmS2W60 & U04620 & c $T$ G A G $T$ g $T$ g $T$ T A a C A c C a G C A \\
\hline Str. faecalis & ENEMSPDPS & M38386 & G T G A c T A a A T c g G C t T C C G C A \\
\hline Str. pneumoniae & SPENDA & X54225 & G a $\mathrm{G}$ A $T$ g $T$ c $T$ T A a $\mathrm{CA}$ a $C \mathrm{GCA}$ \\
\hline Str. pyogenes & STRMRY & M58461 & 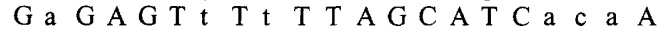 \\
\hline 'Thermophilic bacteria' & $T B A A C P$ & D12512 & 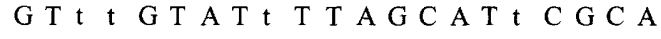 \\
\hline
\end{tabular}

Nucleotides not matching the SERE sequence are presented in lower case. The DNA sequences listed share $>70 \%$ homology with SERE and had consensus, 5'GTGANTNNNNTTNGCNCNGCA at 70\% sequence homology. 
The computerised database search revealed a SERE consensus sequence 5'-GTGANTNNNNTTNGCNCNGCA (5'-GTGANTDTNNTANCATCNGCA for gramnegative and 5'-GNGAGTANNNTADCANCCGCA for gram-positive bacteria at $70 \%$ sequence homology) present in species belonging to at least 42 genera of eubacteria and two genera of archaea (Table 3). Examination of the SERE element suggests the presence of a relatively well-conserved promoter-like hexanucleotide consensus $\left(\mathrm{T}_{80 \%} \mathrm{~A}_{95 \%} \mathrm{~T}_{45 \%} \mathrm{~A}_{60 \%} \mathrm{~A}_{50 \%}\right.$ $\mathrm{T}_{96 \%}$ ) at nucleotide positions $6-12$, and a highly conserved trinucleotide sequence $5^{\prime} \mathrm{GCA}$ at the $3^{\prime}$ end of the sequence. The presence of a promoter-like sequence suggests that SERE may be present within the regulatory region of bacterial genes, as is present upstream of the $\operatorname{sef} A B C D$ operon, and that it may influence gene expression.

\section{Conservation of SERE among different bacterial genera}

To assess the conservation of SERE among eubacteria and archaea, a dot-blot assay was developed with specific chromosomal DNA from eubacterial and archaeal species belonging to seven phyla (Fig. 2).
Results of that analysis suggest that SERE was widely distributed among different genera in both eubacterial and archaeal kingdoms. Furthermore, hybridisation of restriction endonuclease-digested chromosomal DNA from several selected species with radiolabelled SERE oligonucleotide probe supported the dot-blot results and showed that multiple dispersed copies of SERE are present in the genomes of many divergent bacterial phyla (data not shown). Moreover, single primer amplification with SERE of chromosomal DNA yielded results consistent with those from dot-blot hybridisation (Fig. 3). Thus, complex SERE-PCR amplification patterns were observed with many of the species that reacted strongly by dot-blot. Together, these results indicate that SERE is well conserved amongst several distinct genera within eubacterial and archaeal kingdoms.

\section{Application of SERE for genetic fingerprinting of Enteritidis isolates}

The results of SERE-PCR analysis showed that 54 Enteritidis isolates belonging to nine phage types could be assigned to five closely related SERE-PCR patterns, designated A-E (Fig. 4). Sixteen Enteritidis isolates

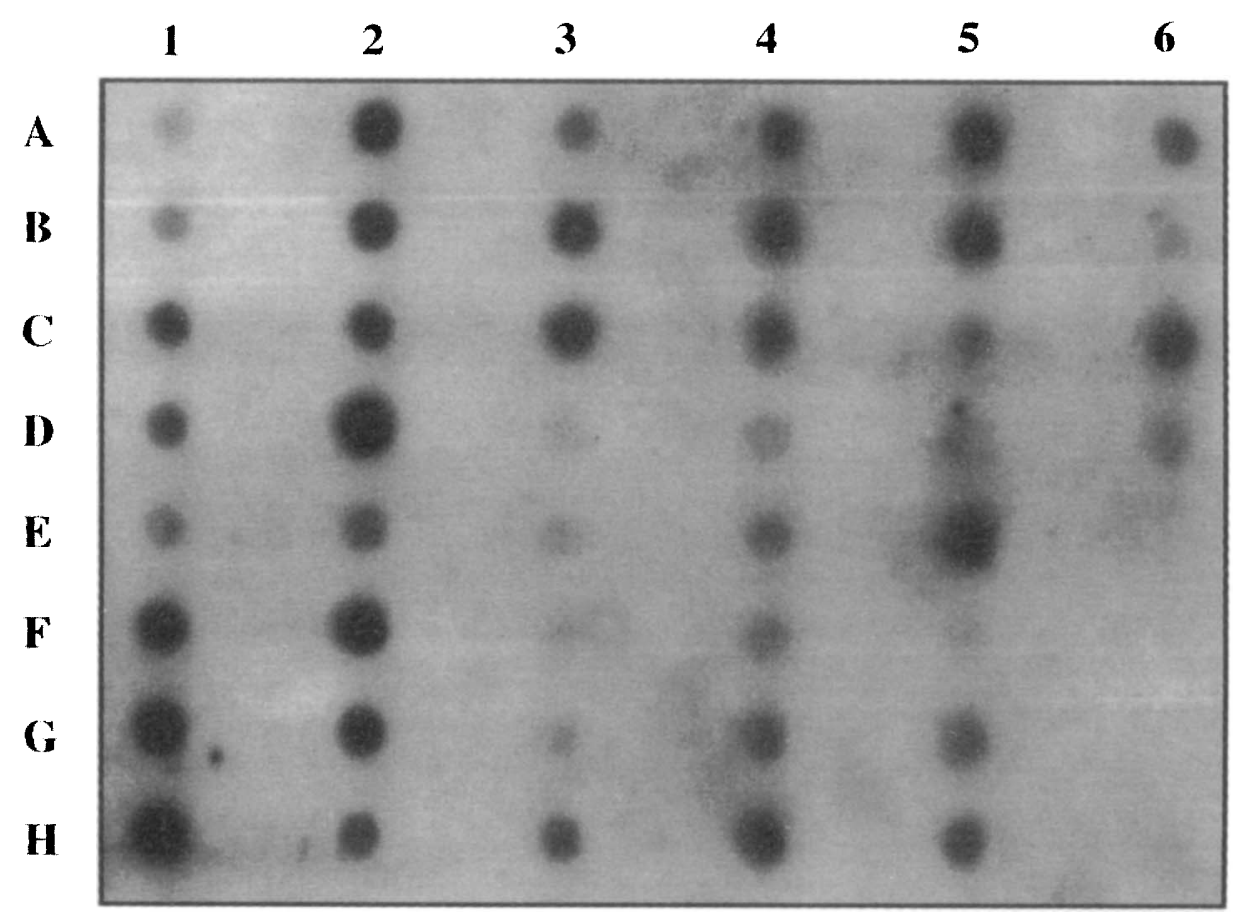

Fig. 2. Distribution of SERE amongst 44 different bacterial species assessed by dot-blot hybridisation. A1, Rhodobacter sphaeroides; A2, S. Enteritidis; A3, Xanthomonas holcicola; A4, Bacillus subtilis; A5, Treponema pallidum; A6, Deinococcus radiophilus; B1, Rhizobium meliloti; B2, C. diversus; B3, Haemophilus influenzae; B4, Listeria monocytogenes; B5, T. vincenti; B6, Thermus thermophilus; C1, Neisseria gonorrhoeae; C2, Klebsiella pneumoniae; C3, Vibrio vulnificus; C4, Staphylococcus aureus; C5, Leptospira interrogans; C6, Herpetosiphon giganteus; D1, N. meningitidis; D2, Ent. sakazakii; D3, Myxococcus xanthus; D4, Str. pneumoniae; D5, Chlorobium vibrioforme; D6, Halobacterium halobium; E1, Sphaerotilus natans; E2, Serratia marcescens; E3, Arthrobacter luteus; E4, Str. pyogenes; E5, Bacteroides fragilis; E6, sterile distilled water; F1, Escherichia coli; F2, Yersinia enterocolitica; F3, Streptomyces albus G; F4, Str. agalactiae; F5, Fusobacterium nucleatum; G1, S. Typhimurium; G2, Proteus vulgaris; G3, Nocardia aerocolonigenes; G4, Caryophanon latum; G5, Flavobacterium meningosepticum; H1, S. Typhi; H2, Pseudomonas aeruginosa; H3, Nocardia otitidiscaviarum; H4, Mycoplasma pneumoniae; H5, Flavobacterium okeanokoites. 


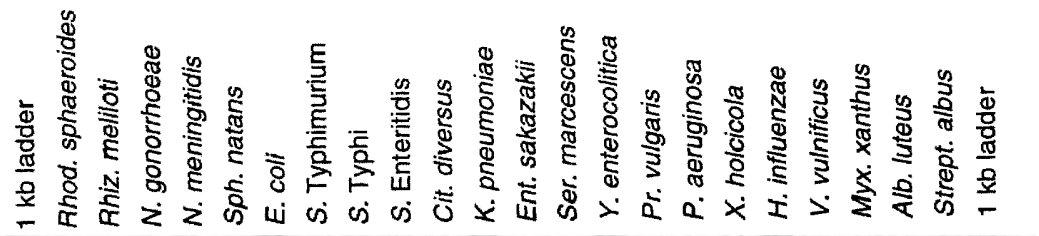

bp
-4072

.

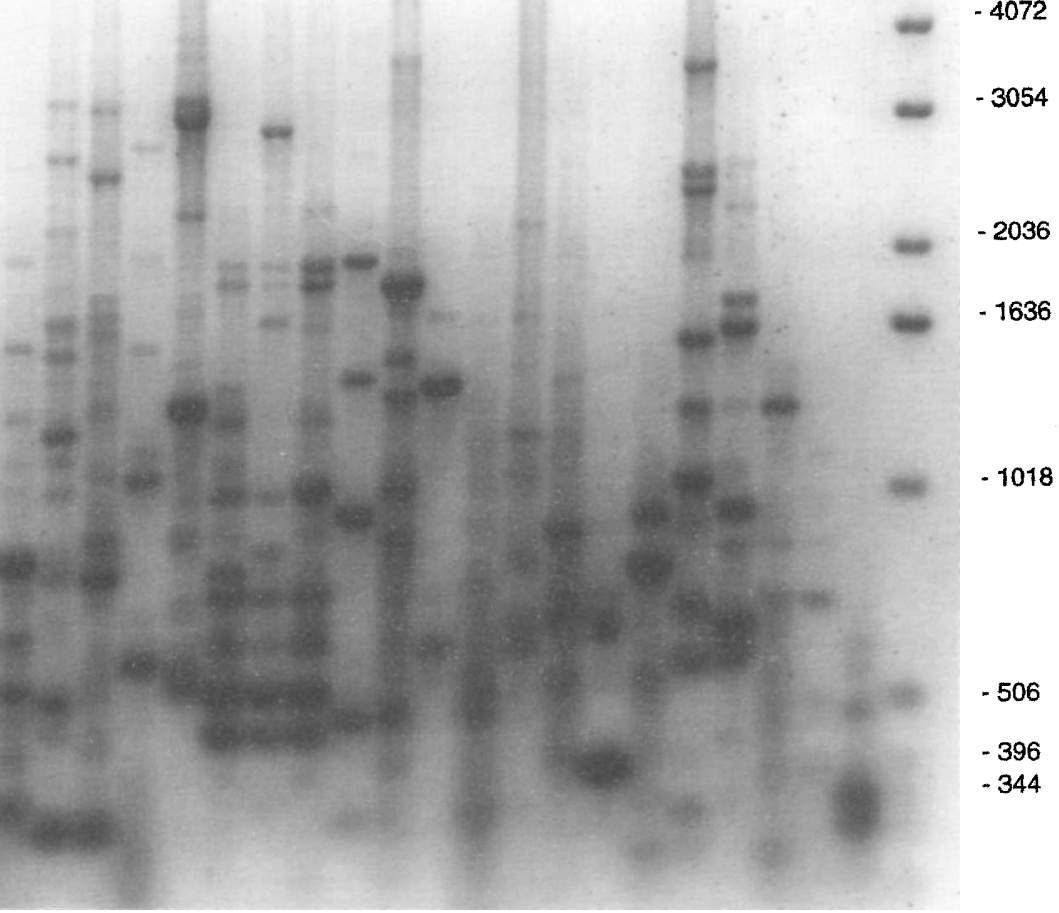

b

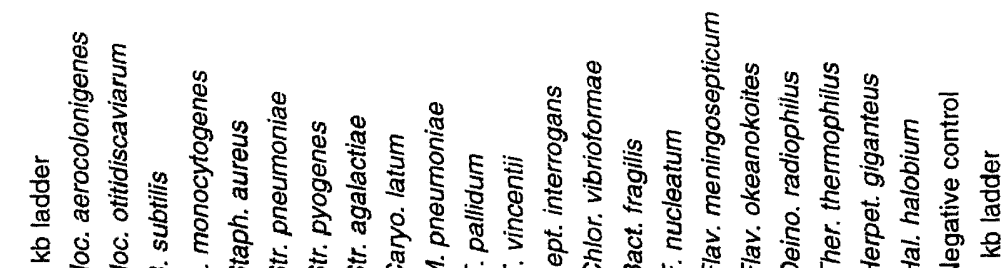

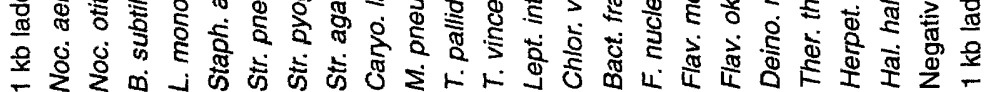




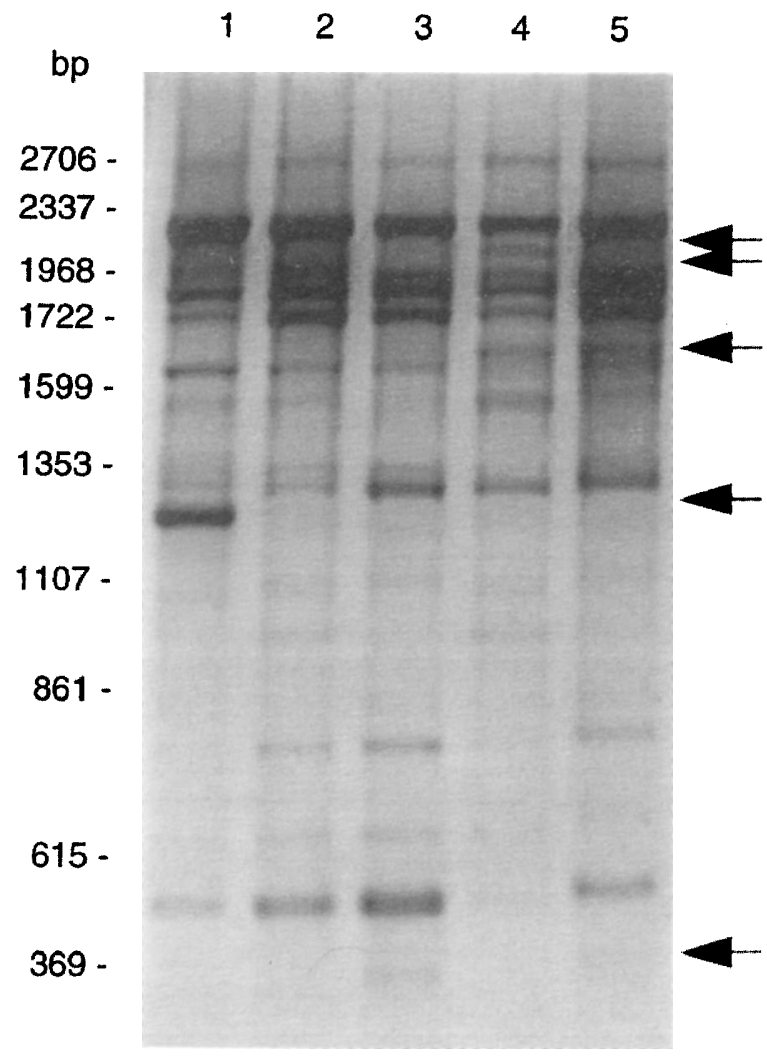

Fig. 4. SERE-PCR fingerprint patterns of Enteritidis isolates showing five fingerprint patterns: lane $1, A ; 2$, $\mathrm{B} ; \mathbf{3}, \mathrm{D} ; \mathbf{4}, \mathrm{E} ; \mathbf{5}, \mathrm{C}$.

belonging to phage types $1,4,7$ and RDNC were assigned to pattern $\mathrm{B} ; 35$ isolates belonging to phage types 7 var, $89 \mathrm{~b}, 13,13 \mathrm{a}, 14 \mathrm{~b}, 28$ and $\mathrm{NK}$ were assigned to pattern $\mathrm{C}$; and one isolate each of phage types $4,14 \mathrm{~b}$ and RDNC were assigned to patterns A, D and $\mathrm{E}$, respectively (Table 1). The index of discrimination (D) [17] of SERE-PCR for these 54 Enteritidis isolates was 0.50 , a value considerably less than that achieved with phage typing $(\mathrm{D}=0.86)$.

\section{SERE-PCR fingerprinting of other Salmonella serotypes}

When a series of 54 strains of other serotypes of Salmonella, including 12 of other O-serogroup D serotypes, was analysed by SERE-PCR, unique fingerprint patterns were obtained for most of the serotypes examined (Fig. 5). The SERE-PCR fingerprint patterns of Enteritidis strains were distinct from those of other salmonellae, including those of other serogroup D serotypes, suggesting that SERE-PCR may be useful for genetic fingerprinting of serotypes of diverse Salmonella serogroups.

\section{Discussion}

A novel repetitive DNA sequence, SERE, identified on the chromosome of Salmonella serotype Enteritidis has been shown to be present in a wide range of species from the eubacterial and archaeal kingdoms. The widespread distribution and presence of internal promoter-like sequences suggest that SERE may be present within the regulatory regions of genes, a hypothesis further supported by the finding that the SERE sequence is located as a tandem inverted repeat forming a stable stem loop (Fig. 1b) within the regulatory region of the $\operatorname{sef} A B C D$ fimbrial operon of Enteritidis [15].

Whilst the exact mechanism by which these repeat sequences have dispersed in the genome and the reasons for their conservation are not clear, several roles have been suggested for their existence. For example, some repeat sequences such as the Escherichia coli REP element have the potential to form stem-loops, thereby regulating gene expression by differential translation within polycistronic operons and retroregulation by mRNA stabilisation [18-21]. REP sequences have also been found to bind DNA polymerase I and DNA gyrases and are believed to be involved in the folding of the nucleoid into independent super-coiled looped domains [18, 19, 22, 23]. Alternate hypotheses for the widespread conservation and dispersal of these elements include the suggestion that they may propagate themselves as selfish DNA by gene conversion through RNA intermediates [24], or that they serve as recombination sites [25], and frequent exchange of information by recombination at these sites may serve to retain these repeated elements with a high degree of sequence conservation. Although the results of this investigation do not exclude any of these hypotheses, the presence of SERE in the regulatory region of bacterial genes, as well as the presence of promoterlike elements and evidence of secondary structures, suggest that SERE may be involved in the regulation of gene expression by mediating DNA-protein interactions.

In general, species that reacted strongly in the dotblot assay yielded complex SERE-PCR patterns and vice versa (Figs. 2 and 3). However, with isolates of C. diversus, Ent. sakazakii, Pseudomonas aeruginosa and Nocardia otitidiscaviarum, the strong intensity of signal observed by dot-blot was not reflected by a correspondingly increased complexity of SERE-PCR fingerprint patterns. Although the reasons for this discrepancy are not exactly known, these results may be due to a greater spacing of the repetitive element, very close opposition of the repetitive element, or to the same orientation of the repeat sequences to each other within the genome. By contrast, isolates of Str. pneumoniae, Str. agalactiae, Str. pyogenes, Leptospira interrogans, Fusobacterium nucleatum, Chlorobium vibrioforme and Halobacterium halobium gave relatively complex SERE-PCR fingerprint patterns, although they reacted weakly on dot-blot (Fig. 3). These results may partly reflect an altered GC content in these species. 

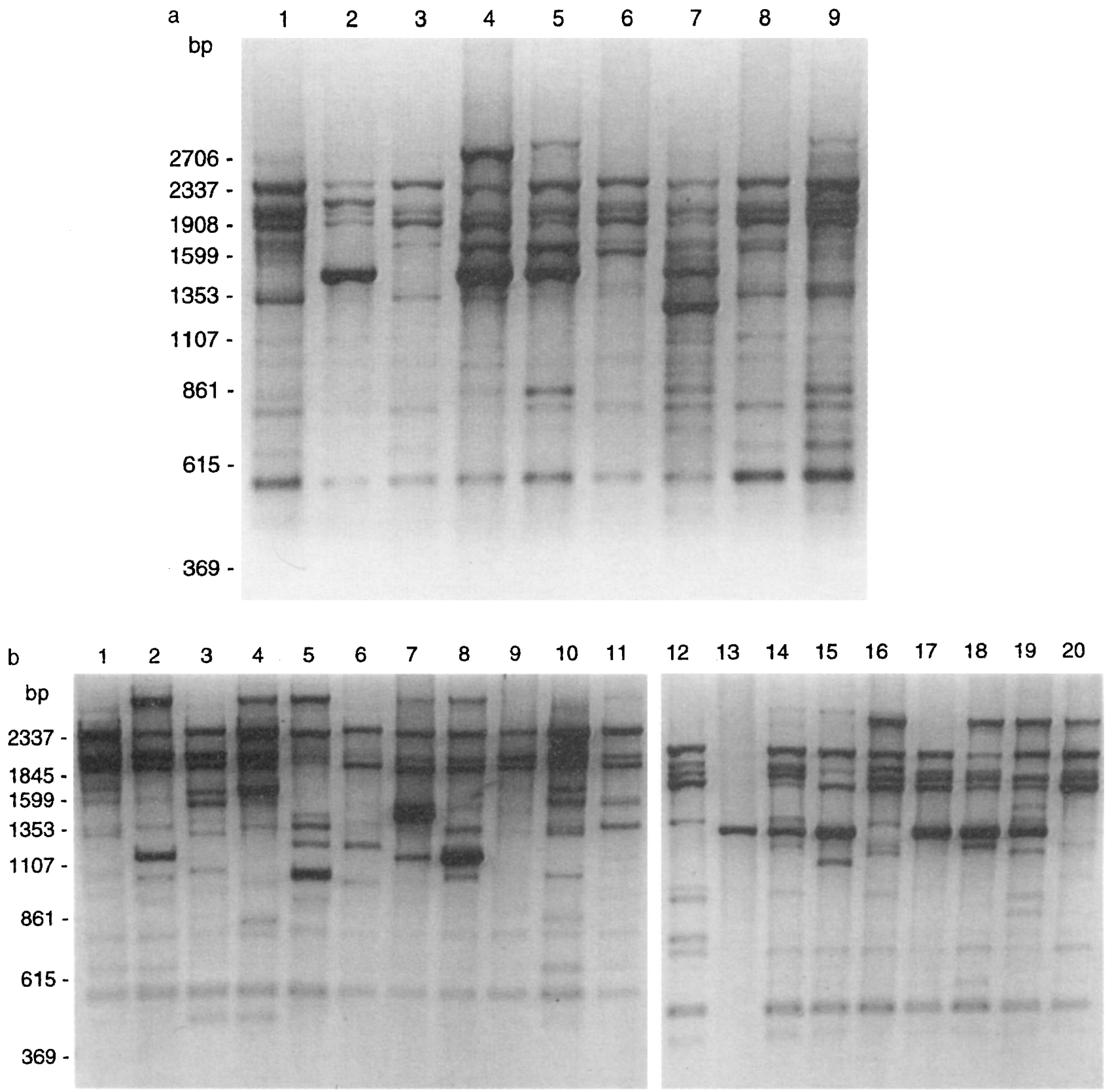

Fig. 5. SERE-PCR fingerprint profiles of serotypes of Salmonella. A, O-serogroup D serotypes: lane 1, Enteritidis; 2, Javiana; 3, Moscow; 4, Miami; 5, Durban; 6, Pullorum; 7, Panama; 8, Gallinarum; 9, Dublin; B, 19 serotypes of other O-serogroups: lane 1, Enteritidis; 2, Livingstone; 3, Brandenburg; 4, Arizonae; 5, Braenderup; 6, Oranienburg; 7, Heidelberg; 8, Worthington; 9, Hadar; 10, Typhimurium; 11, Blockley; 12, Chester; 13, California; 14, Bareilly; 15, Abortusequi; 16, Anatum; 17, Tennessee; 18, Kentucky, 19, Drypool; 20, Senftenberg.

The results of this investigation showed SERE-PCR to be less discriminatory than phage typing, a finding that may suggest that resistance or susceptibility to bacteriophages is under strong evolutionary pressure and, hence, evolving at a more rapid rate than the rest of the bacterial genome. The five distinct SERE-PCR fingerprint patterns identified among isolates of Enteritidis were very similar. This limited heterogeneity of fingerprint patterns among Enteritidis isolates from various distinct host species and geographic locations may reflect either a relatively recent origin of serotype Enteritidis or a widespread dissemination of one highly virulent Enteritidis clone. These hypotheses are consistent with the findings of a multilocus enzyme electrophoretic analysis of Enteritidis isolates that revealed a restricted genetic diversity in this serotype and showed that most (93\%) Enteritidis isolates from world-wide sources were represented by one clone, En1 [26]. Analysis of Enteritidis strains from sporadic cases and outbreaks by pulsed field-gel electrophoresis and ribotyping have also indicated the limited genetic diversity of this serotype [27].

In conclusion, the results of the present investigation show that the paucity of heterogeneity in SERE-PCR 
fingerprint patterns may be utilised to develop speciesand serogroup-specific fingerprint patterns for isolates of $S$. Enteritidis. Further studies to determine whether the amplified fragments are unique to $S$. Enteritidis are in progress.

Research in the laboratory of V.K. is supported by grants from the Minnesota Agricultural Experiment Station, the Minnesota Turkey Growers Association, and the National Institutes for Health. We thank Alongkorn Amonsin, Shirin Munir and Dennise Towney for their comments and suggestions for improving the manuscript.

\section{References}

1. Lupski JR, Weinstock GM. Short, interspersed repetitive DNA sequences in prokaryotic genomes. $J$ Bacteriol 1992; 174: 4525-4529.

2. Dimri GP, Rudd KE, Morgan MK, Bayat H, Ames GF-L. Physical mapping of repetitive extragenic palindromic sequences in Escherichia coli and phylogenetic distribution among Escherichia coli strains and other enteric bacteria. $J$ Bacteriol 1992; 174: 4583-4593.

3. Gilson E, Clément J-M, Brutlag D, Hofnung M. A family of dispersed repetitive extragenic palindromic DNA sequences in E. coli. EMBO J 1984; 3: 1417-1421.

4. Higgins CF, Ames GF-L, Barnes WM, Clement JM, Hofnung M. A novel intercistronic regulatory element of prokaryotic operons. Nature 1982; 298: 760-762.

5. Hulton CSJ, Higgins CF, Sharp PM. ERIC sequences: a novel family of repetitive elements in the genomes of Escherichia coli, Salmonella typhimurium and other enterobacteria. Mol Microbiol 1991; 5: 825-834.

6. Sharples GJ, Lloyd RG. A novel repeated DNA sequence located in the intergenic regions of bacterial chromosomes. Nucleic Acids Res 1990; 18: 6503-6508.

7. Martin B, Humbert O, Camara M et al. A highly conserved repeated DNA element located in the chromosome of Streptococcus pneumoniae. Nucleic Acids Res 1992; 20: 3479-3483.

8. Versalovic J, Koeuth T, Lupski JR. Distribution of repetitive DNA sequences in eubacteria and application to fingerprinting of bacterial genomes. Nucleic Acids Res 1991; 19: 6823-6831.

9. Versalovic J, Schneider M, De Bruijn FJ, Lupski JR. Genomic fingerprinting of bacteria using repetitive sequence-based polymerase chain reaction. Methods Mol Cell Biol 1994; 5: $25-40$.

10. Del Vecchio VG, Petroziello JM, Gress MJ et al. Molecular genotyping of methicillin-resistant Staphylococcus aureus via fluorophore-enhanced repetitive-sequence PCR. J Clin Microbiol 1995; 33: 2141-2144.

11. Versalovic J, Kapur V, Koeuth $\mathrm{T}$ et al. DNA fingerprinting of pathogenic bacteria by fluorophore-enhanced repetitive se- quence-based polymerase chain reaction. Arch Pathol Lab Med 1995; 119: 23-29.

12. Versalovic J, Lupski JR. Distinguishing bacterial and fungal pathogens by repetitive sequence-based PCR (rep-PCR). Lab Medica International 1996; XIII: 7-8.

13. Koeuth T, Versalovic J, Lupski JR. Differential subsequence conservation of interspersed repetitive Streptococcus pneumoniae BOX elements in diverse bacteria. Genome Res 1995; 5 : $408-418$.

14. Woese CR. Bacterial evolution. Microbiol Rev 1987; 51: $221-271$.

15. Clouthier SC, Müller K-H, Doran JL, Collinson SK, Kay WW. Characterization of three fimbrial genes, sefABC, of Salmonella enteritidis. J Bacteriol 1993; 175: 2523-2533.

16. Clouthier SC, Collinson SK, Kay WW. Unique fimbriae-like structures encoded by $s e f D$ of the SEF14 fimbrial gene cluster of Salmonella enteritidis. Mol Microbiol 1994; 12: 893-903.

17. Hunter PR, Gaston MA. Numerical index of the discriminatory ability of typing systems: an application of Simpson's index of diversity. $J$ Clin Microbiol 1988; 26: 2465-2466.

18. Newbury SF, Smith NH, Higgins CF. Differential mRNA stability controls relative gene expression within a polycistronic operon. Cell 1987; 51: 1131-1143.

19. Newbury SF, Smith NH, Robinson EC, Hiles ID, Higgins CF. Stabilization of translationally active mRNA by prokaryotic REP sequences. Cell 1987; 48: 297-310.

20. Stern MJ, Ames GF-L, Smith NH, Robinson EC, Higgins CF Repetitive extragenic palindromic sequences: a major component of the bacterial genome. Cell 1984; 37: 1015-1026.

21. Stern MJ, Prossnitz E, Ames GFL. Role of the intercistronic region and post-transcriptional control of gene expression in histidine transport operon of Salmonella typhimurium: involvement of REP sequences. Mol Microbiol 1988; 2: 141-152.

22. Gilson E, Clement JM, Perrin S, Hofnung M. Palindromic units: a case of highly repetitive DNA sequences in bacteria. Trends Genet 1987; 3: 226-230.

23. Yang Y, Ames GF-L. DNA gyrase binds to the family of prokaryotic repetitive extragenic palindromic sequences. Proc Natl Acad Sci USA 1988, 85: 8850-8854.

24. Higgins CF, McLaren RS, Newbury SF. Repetitive extragenic palindromic sequences, mRNA stability and gene expression: evolution by gene conversion? A review. Gene 1988; 72: 3-14.

25. Watt VM, Ingles CJ, Urdea MS, Rutter WJ. Homology requirements for recombination in Escherichia coli. Proc Natl Acad Sci USA 1985; 82: 4768-4772.

26. Beltran P, Musser JM, Helmuth $\mathrm{R}$ et al. Toward a population genetic analysis of Salmonella: genetic diversity and relationships among strains of serotypes $S$. choleraesuis, $S$. derby, $S$ dublin, $S$. enteritidis, $S$. heidelberg, $S$. infantis, $S$. newport, and S. typhimurium. Proc Natl Acad Sci USA 1988; 85: 77537757.

27. Thong K-L, Ngeow Y-F, Altwegg M, Navaratnam P, Pang T. Molecular analysis of Salmonella enteritidis by pulsed-field gel electrophoresis and ribotyping. J Clin Microbiol 1995; 33: $1070-1074$ 